\title{
Transformation of Bank Capital Regulation in Ukraine: the Role of Institutional Distortions
}

\section{Viktor Koziuk}

Dr., Professor, member of the Council of National Bank of Ukraine, Academician of the Academy of Economic Sciences of Ukraine, Head of the Department of Economic Theory of Ternopil National Economic University, Ukraine.

\begin{abstract}
It is shown that reforms of banks regulatory requirements in Ukraine take place in global context of changes in banking regulation under Basel III implementation. It is proved that Basel III implementation helps not only to enhance financial stability but also solve plenty of problems related to institutional weakness. The fact of fundamental undercapitalization of Ukrainian banking system is shown as well as inability of such system to be resistant against NPL hikes even in time of formal suitability to formal regulatory norms. This confirms fact that previous banking regulation model was "blind" and unable to react adequately to institutional distortions. It's shown that Basel III implementation in Ukraine all together with risk-oriented bank supervision first of all are addressed to institutional challenges that make procyclicality and risk concentration problems more radical.
\end{abstract}

Key words: Basel III, bank regulation, bank capital, bank assets, oligarchical banking, institutional weakness. JEL Classification: G21.

(C) The Author, 2017. This article is published with open access at ARMG Publishing.

\section{Introduction}

Global Crisis and Changes in Approaches to Banking Regulation. The response to the global financial crisis is evident of a profound reinterpretation of banking regulations. The emergence of strong pro-cyclical effects of the financial system, the question of the nature of risk assessment and its relation to capital adequacy, the growing importance of the business model of financial intermediaries for technology policy implementation etc. financial stability affected the overall trend towards tighter banking regulation. Although implementation of new approaches in many countries coincided in time with the contract on credit activity and close to zero interest rate, thus using activity criticism from the financial sector, the fact remains unambiguous that focus on strengthening financial stability and ability of financial institutions is steady. In fact, the changes taking place in the NBU's approaches to banking regulation reflected the general trend in the mainstream, which today is considered to be generally accepted.

Among the main changes in approaches to banking capital regulation are: an increase in capital requirements; introduction of capital buffers is intended to reduce risks of procyclicality and system significance of financial institutions; increase in liquidity requirements; the introduction of leverage regulation, which would have limited ability of banks to attract external financing, increasing the role of owners' funds. In parallel occurs: the establishment of surveillance system based on the principles of risk assessment (forward-looking), but not solely on the basis of a backward-looking calculating; the introduction of separate capital requirements and supervisory system for systemically important financial institutions (Basel III, European Banking Union); integration of micro- and macro-prudential regulation in the aspect of identifying the risks of procyclicality and systemic vulnerability of the financial system; raising the responsibility of owners and creditors (the bailin procedure of $8 \%$ assets is an integral part of the bank resolution mechanism in the European Banking Union), etc.

At the same time, changes in banking regulation in Ukraine are realized within the framework of specific structure distortions inherent in institutional weak economics in which financial instability is reproduced through:

- politically motivated manipulation of banking supervision procedure;

- dominance of insider operations;

- offshore as a way to minimize the timely identification risk of related transactions by regulators;

- hiding final beneficiaries of transactions to circumvent regulatory restrictions; 
- fundamental undercapitalization of financial institutions that are able to manipulate the level of actual risk and avoid capital raising imperatives in accordance with regulatory requirements, etc.

This raise the question of how changes in approaches to the regulation of Bank capital, the NBU exclusive follows the Basel III requirements and how to overcome the institutional distortions in the banking system of Ukraine can be realized through the key elements of such claims. The question of identification of the providing adequacy problem of the banking system capital in previous periods in light of the transition to the new model regulation is extremely relevant, and the question of how such a model can be addressed to the structure challenges of oligarchic banking.

\section{Literature review}

Justification of the approach to banking capital regulation, addressed to the problem of procycles and concentration risks, is widely cover in several papers, particular in the aspect of necessity for addition buffers, which, however, increase the burden on the banks owners (BIS, 2010; BIS, 2013; Baker, 2013). In the light of significantly changes in approaches to the regulation of Bank capital preliminary studies quite clearly structure around a number of problems.

First, bank capital is considered from the position of the fundamental theoretical arguments in favor of banking regulation. Within this approach, special attention is paid to how number construction of economic regulations should, in principle, rely on the calculating of risk weighted assets. This problem stems from the fact that, in fact, a number of key regulatory indicators become dependent on risk assessment methods and the willingness of management to objectively reflect them (Kashyap, 2008; Santos, 2000). The introduction of leverage regulation should eliminate the problem of risk assessment quality in determining the amount of capital adequacy (Gambacorta, 2016). Similarly, the specificity of banking activities leads to the fact that the arguments of the M-M theorem are not relevant. The latter opens the way for an explanation of why the financing structure of banks can be subject to regulation (Dagher, 2016).

Secondly, the optimal value choice of regulatory requirements for bank capital is a theoretical dilemma, since the choice is limited to alternative (trade-off): or increase the stability of the banking sector, or more elastic transformation of bank liabilities into liquidity and solvency units available to borrowers. With the model of Diamond and Rajan, 2000 it is evident that the regulator, choosing an optimal amount of regulatory capital, may fall under the political and economic shift of its own preferences. In other words, the domination of emphasis on financial stability will affect the regulatory requirements of one type, and considerations of credit incentives for the economy - the other one.

Thirdly, the optimum value of bank capital can be derived from its ability to compensate for shocks and to adapt financial institutions to a sharp increase in non-performing assets. Similarly, optimality can be deduced from the magnitude of fiscal losses that are generated by crises. In both cases, the empirical data indicate that the optimal value of bank capital varies between $15-23 \%$, on the one hand, significantly exceeding the norm of Basel, on the other hand, being in the maximum zone of the Basel III requirements ( Dagher, 2016; Dimand, 2000; BIS, 2010).

Fourth, taking into account the transition to higher capital adequacy ratios for the fact, the speed of such a transition remains in the light of the fact that pre-capitalization in the short run may conflict with the size of the aggregated loan. As a rule, this argument is put forward to explain why the transition to Basel III after the crisis poses risks of slowing the economic recovery (Gambacorta, 2016). Also under the same angle examines the vulnerability of macroprudential instruments to criticism from the fiscal burden of counter-cyclical regulation. At the same time, higher capital requirements may be more conducive to economic growth in the long term (financial channel stability and channels risk-taking) compared to short-term (interest margin).

The analysis of the banking systems institutional weaknesses traditionally focuses on the issues associated lending. In such studies, the emphasis is on the fact that it is not solely the result of creditors' adaptation to significantly costs of monitoring borrowers, but rather is an adaptation to the lack of creditors' rights protection (Tirole, 2006). On the other hand, it is a channel for transferring risks to outsiders, so that is a way of avoiding responsibility on the part of owners (La Porta, 2003; Rajan, 1992; La Porta 1997). Although empirical evidence indicates that it will be lending 'evil', is determined primarily by the quality of institutions (Cull, 2006). However, as empirical studies show that the depth of banking crises is also higher in countries characterized by weak institutions (Laeven, 2012). 
Bank regulation reforms in Ukraine have recently been subject to polar assessments, which are largely outside the context of changes in approaches to the formation of a new regulatory environment in the world. At the same time, specific national institutional distortions in banking are not unique in light of emerging markets experience. However, there is a need to consider the case of Ukraine in the context of changes in bank capital requirements both in addressing Basel III problem of procyclicality and the problem of vulnerability to institutional weaknesses. The main purpose of the article is to demonstrate that the fundamental undercapitalization of Ukraine's banking system is a manifestation of institutional distortions, the overcoming of which are the relevant reforms.

\section{Institutional anatomy of the oligarchical banking and framework conditions reform of banking regulation in Ukraine}

Considerable losses of capital by the domestic banking system and the high level of financial instability associated with the insolvency of a significant number of banks have reflected not only the direct consequences of the military conflict, the rigorous macroeconomic correction of accumulated imbalances, but also the frustration of banking regulation by 2015 (the peak of the crisis), the insolvent to identify the scale and structure of risks, to ensure transparency of ownership structure, compliance with the standards of related operations and, ultimately, to ensure level of capitalization commensurate with the level of risk. Under criticism (in fact, political resistance) implementation of new approaches to banking regulation, the introduction of new models of capitalization and risk identification, corporate governance in banks etc. seemingly incompatible with the level of development of the domestic financial sector conceals the fact that such approaches substantially restrict (reduce the systemic significance) traditional practices for the functioning of political business groups with their specific models of oligarchic banking, which are traditional for the national economy.

The starting point for implementing the new framework conditions for banking regulation was almost complete institutional distortion of the functioning of Ukraine`s banking system. Non-transparent ownership structure, insider lending, offshore operations were implemented in order to redistribute depositors and lenders to owners and management. It should be emphasized that such a triad was formed not only as a way of deliberately causing losses to outsiders due to information asymmetry, but also as a way of adapting to a distorted institutional environment for doing business in Ukraine. The lack of protection of creditors' rights, raiding, strict division of assets according to the criterion of belonging to the interests of one or another political business group, the lack of borrower's transparency and significant costs of borrower's quality monitoring in aggregate affected the rooting practices insider relations.

As a result, opaque ownership, related operations, and offshore were a way to circumvent regulatory restrictions (above all, restrictions on the substantial possession of the bank, limits on transactions with insiders, etc.):

- making banking supervision "blind" to the nature of concentration risk and assessment of the actual level;

- turning non-performing assets relative to the strength accountability of borrowers' operations;

- frustrating the regulatory content of economic norms and eventually lowering actual capital requirements, etc.

Identification of owners and end beneficiaries, conducting stress testing, changing the methodology of identifying related persons, etc. during 2015-2016 laid the foundation for restoring stability in the financial sector and further changes in banking regulation.

The framework conditions for the transformation of banking regulation are laid down in the Comprehensive Program for the Development of the Financial Sector of Ukraine until 2020. The implementation of this program is related to the fulfillment of a number of Ukraine's commitments to the IMF and within the framework of the EU-Ukraine Association Agreement (implementation of the CRD IV 2013/36 / EU and CRR 2013/575 / EU). This Program aims to create the institutional foundation for a sound banking system that meets transparency, shock resistance, adequacy of risk assessment and capital adequacy, supervisory effectiveness and targeting to ensure systemic financial stability and individual sustainability of financial institutions. In the aspect of changing the approaches to banking regulation, the Program provides:

- implementation of Basel III capital and liquidity;

- the introduction of the Basel principles for effective banking supervision; 
- the introduction of a new procedure for credit risks assessment;

- introduction of risk based risk assessment, early response, SREP banking monitoring technologies, including clustering of banks according to the business model criterion;

- introduction of a new format of supervisory reporting (UBPR) and improvement of the CAMELS system;

- the introduction of new approaches to corporate governance in banks, etc.

The indicated changes are structural in their content and are designed for the appearance of long-term positive effects. These structural changes are designed to lay new institutional foundations for ensuring financial stability as a prerequisite for the development of the banking system and the restoration of sustainable economic growth.

\section{The fundamental undercapitalization of Ukrainian banking system}

According to the formal assessment of the "Regulatory capital ratio to risk weighted assets" of Ukrainian banking system maintains a level of capitalization that can be described as follows: from minimally acceptable to a sufficient (except for the 3rd quarter of 2015, when the rate fell to $7.09 \%$ ). At the end of 2005 the value was $14.95 \%$ at the end of the crisis $2008-14,01 \%$, respectively, in $2009-18,08 \%, 2010-20,83 \%, 2011-$ $18,90 \%, 2012-18,06 \%, 2013-18,26 \%, 2014-15,60 \%, 2015-12,31 \%, 2016-12,69 \%$. For the first quarter of 2017 , this value slightly increased and reached $13,72 \%$.

On the one hand, a trend to lower capitalization of Ukrainian banking system was formed in 2011, confirming the strengthening of negative processes in the sphere of politically motivated supervision. On the other hand, the level of capitalization by 2015 formally corresponds to a range of $15-23 \%$ optimal values, determined on the basis of the IMF methodology, which emphasizes the ability of capital to absorb the shocks of asset quality loss and takes into account statistics on the magnitude of non-performing loans at the peak of crises, their transformation shares into lost assets, the size of the reserve and the ratio between assets and risk weighted assets. This methodology provides a calculation of the relative importance of bank capital in accordance with the formula (1):

Bank capital $=(N P L * L G D-$ Provisions $+1 \%) *($ Total Assets $/$ Risk Weighted Assets $)(1)$,

where: $N P L$ - the value of non-performing loans; $L G D$ - the share of bad loans, which turns into a hopeless loss; Provisions - the value of redundancy; Total Assets - total assets; Risk Weighted Assets - assets weighted for risk (Dagher, 2016).

However, the recalculation (on the basis of this methodology) of the optimal values of capital for Ukrainian banking system taking into account the value of non-performing loans of the future period show significant discrepancies with the actual data. If during the crisis in 2008 this value was $9.11 \%$ (for formally actual $14,01 \%)$, in $2013-16,22 \%(18,26 \%)$ in $2014-23.32 \%(15,60 \%)$, in $2015-26.79 \%(12,31 \%)$, in $2016-$ $38,01 \%(12,69 \%)$. That is, the theoretical value of the optimal amount of capital for 2013 was lower than actual and after - much higher. This distinction indicates a failure of the capital of Ukrainian banking system to perform its key function - to absorb the shock of non-performing assets despite the fact that the latter are influenced by the recognition of asset quality post factum.

The inadequacy of the prevailing risk assessment practices, which ultimately led to a downsizing of capital needed to maintain a representative stressor of the Ukrainian banking system, also manifests itself in the ratio of assets to weighted assets. This indicator is commonly used at 1.75 (Dagher, 2016). Its calculation for the domestic banking system in 2008 was 1.05 (net assets and 1.1 gross assets), in $2013-1.14$ (respectively, 1.26), in $2014-1.09(1,22)$, in $2015-1.20(1.49)$, in $2016-1.48(2.01)$, in the first quarter of $2017-1.77(2.41)$. That is, the approximation of this indicator to the usually world banking practice took place only from 2015 , after the NBU began stress testing, identified large-scale scheme of related lending, identified the concentration of risks and their inadequate assessment. The most striking changes of this indicator occurred in 2016-2017 as a result of problematic portfolio identification of PrivatBank.

The low value ratio between assets and risk weighted assets should point to the fact that the domestic banking system is completely intolerant to risk. However, during the crisis of 2008-2009 and 2014-2016, a sharp increase in non-performing loans showed a paradoxical mismatch between the so-called low level of banking activity "riskiness" and loss of asset quality. The usual value of the ratio between assets and risk weighted assets $(1,75)$ corresponds to the median value of NPL to assets at the level $18 \%$ for developed countries and 
$20-30 \%$ for countries with medium and low incomes. Then for Ukraine according to the NBU, the share of NPL in assets was $11.4 \%$ in 2008, 19,54\% in 2013, $27.65 \%$ in $2014,31,62 \%$ in $2015,44,44 \%$ in 2016.

The gap in these indicators indicates that the actual state of risk taking level and capital adequacy of Ukrainian banking system was not true. The banks underestimated the risk of the operations and/or did not adequately reflect the risks, with the result that the ratio of assets to risk weighted assets looked unrealistic and was moving in the direction of representative values solely due to the change in policies and instruments of banking regulation. On the other hand, formally, a banking system with intolerant attitude to risk was found to be extremely ineffective in returning loans, which could indicate the hidden nature of actual risks, the manipulation of which is possible due to controlled transactions and / or fraud. Numerous testimonies of legislation violations and regulatory requirements by owners and top management of many banks confirm this thesis.

The fundamental undercapitalization of the banking system against the background of formal compliance with most economic standards indicates the reluctance of owners and managers to assume the risk of financial institutions functioning and to bear their own costs. Due to the prevailing practices of related lending, such a risk systematically translated into bank lenders (deposit holders) and taxpayers (pre-capitalization, payment of guaranteed amounts of deposits in banks recognized as insolvent). This led to the systemic vulnerability of the entire banking system and the loss of confidence in it. Possibilities to transfer risks to creditors and taxpayers and to avoid the costs of banks capitalization according to the actual level of risk turned out to be a direct consequence of institutional distortions in the field of banking regulation, the replacement of which should be based on the independence of the NBU in the area of micro and macroprudential policy implementation.

\section{The recapitalization and the implementation of Basel III requirements}

Systemic Ukrainian banks undercapitalization was confirmed by stress testing, which was started in 2015 and has covered almost all solvent banks, accounting for more than $96 \%$ of banking system assets in general. Expansion of information about the actual state of PrivatBank asset quality reflects the vulnerability of the entire banking system to an underestimation of risks level with the purpose of owners' disengagement from the recapitalization of financial institutions. Stress tests also showed the need for large-scale capitalization of banks and increase of regulatory requirements to the minimum amount of authorized capital.

It is introduced new minimum requirements to the authorized capital - UAH 120 million for existing banks and UAH 500 million for new banks - reflect the need to increase the level of capitalization and indirectly raise the level of owners' responsibility (the effect of "skin in the game"). New requirements are based on the results of stress tests and should not be seen as discriminatory against already functioning banks, since they take into account the actual level of risk. In this sense, such requirements do not constitute barriers to market presence. Increased requirements for new banks have to demonstrate a combination of banking capital concentration and the parallel increased competition in the segment of the largest banks.

Together with the increase in the requirements for the authorized capital and the withdrawal of insolvent banks, the structure of the banking system by the size of the authorized capital is changing. If on 01.01.2015, the number of banks with authorized capital less than UAH 120 million was 30, in accordance with the magnitude from 120 to 200 million - 46, from 200 to 300 million - 25, 300 to 500 million 21, more than 500 million $41,01.01 .2017$, the corresponding amount of banks amounted to $1,42,16,11,30$. Such changes indicate parallel processes of concentration (share of 20 largest banks in the net assets was $89.4 \%$ at the beginning of 2017, compared to 86.4 per cent at the end of 2015; at the same time at the end of 2016 top 5 banks accounted for $56.1 \%$ of the banking system net assets) and segmentation of the banking system, which would combine the tendencies towards oligopoly with monopolistic competition. Also, these changes will cause increased segmentation by the criterion of a business models that will require the transformation of banking supervision and development of risk-based oversight tools.

Along with the implementation of the requirements for the capitalization of the banking system from 01.01.2019, the transition to a new model of minimum capital requirements based on the principles of Basel III is planned. Current model allows for the formation of the minimum capital in the amount of $10 \%$ of assets in the context $5 \%$ of the fixed capital and no more than $5 \%$ of additional capital. From 01.01 .2019 , the requirements for the structure of the minimum requirements will change: $7 \%$ of fixed capital and $3 \%$ of additional capital. From 01.01.2020, to the specified requirements, a buffer of conservation $(0.625 \%)$ and a system-importance buffer of 1-2\% for systemically important banks are added. Such requirements increase the owners' responsibility for the capital of financial institutions, but simultaneously strengthen the integration of 
the micro and macroprudential approach to counteract the risk of procyclicality and cross-sectoral vulnerability of the financial system. Together, it is worth noting that the new minimum capital requirements still look more benign compared to the full package of Basel III, which requires a minimum value of core and additional capital at a level of $8 \%+2.5 \%$ a conservation buffer $+0-2, \%$ countercyclical buffer, $+0-5 \%$ for globally systemically important banks. The expected difference between the minimum requirements of Basel III and the new requirements in Ukraine (based on the maximum values) is significant: $18 \%$ versus $12.625 \%$.

An important component of Basel III requirements is the introduction of restrictions on the amount of banking leverage. In Ukraine, the introduction of the requirement to maintain a ratio between first-level capital to nonweighted assets is expected from 01.01.2018. This requirement in the case of Ukraine has a fundamental value, since it minimizes the impact of distortions in risk assessment on capital adequacy ratios. This means that keeping the necessary proportions between equity and assets will limit the ability to shift the structure of liabilities towards external financing through risk-based manipulations that affect the size of risk weighted assets. Also such requirement reduces the regulator's discretion regarding the assessment of compliance with capital adequacy and leverage standards, making banking supervision vulnerable to political pressures or other institutional distortions. Despite the fact that the introductions in the framework of the Basel III requirements maintain a 3\% ratio between first-tier capital and risk free assets is intended to reduce the banks' inclination to excessive foreclosure and dependence on the market for direct bank loans, in Ukraine this requirement has important institutional significance. Restrictions on the funding structure will be determined on the basis of a database, free of possible risk assessment misuse. If, theoretically, the introduction of the leverage ratio is intended to minimize the risk procycles in banks' behavior due to asymmetric risk assessment during the financial cycle (underestimation in the phase of boom, the revaluation of the contraction phase), in conditions of institutional weakness, this approach allows to prevent the decrease in the value of financing through equity due to the manipulation of risk assessment and, accordingly, the overstatement of risk weighted assets.

The process of transition to new standards of the minimum size of authorized capital is theoretically considered the most controversial component of the banking system capitalization. The hypothetically larger share of equity financing should be attributed to an increase in the cost of resources offered to borrowers. Similarly, the increased regulatory burden is seen as a factor in the increase in intermediation fees, which may affect the increase of long-term rates for active operations. At the same time, a well-capitalized banking system can function to raise the bar of acceptable risks, thereby affecting the reduction of real effective and median lending rates. A smooth transition to new standards of the minimum allowable volume of capital, as well as the minimum allowable values of regulatory capital, is considered optimal for reasons of losses and benefits balance.

The trajectory of the capitalization, chosen by the NBU, can be considered to be conditional on the criteria for a smooth transition. The minimum value of the authorized capital is 200 million UAH should be reached in 2017, and 500 million UAH - until July 2024. A factor that mitigates the requirements for bank capitalization is the introduction by the NBU in 2016 permissions to reduce credit risk at the expense of: arrears repayment on problem loans (including through realization of the mortgagee rights); loans execution for additional (in some cases new) quality assurance. Such an approach has expanded flexibility in the process of capital increase and is faced with the problem of a significant proportion of related loans, such as those provided with doubtful deposits (for reasons of actual market value or liquidity). Despite the fact that the implementation of such an approach may lead to reservations about excessive discretion by the NBU in assessing risks and the final amount of required contributions to capital, it is a reflection of a certain compromise designed to optimize the costs of owners in order to limit their motivation to withdraw money from the bank in case if they decided to leave the banking business and do it in a way of withdrawing assets. However, unlike most of the countries affected by the global financial and European debt crisis, Ukrainian banking system was fundamentally undercapitalized, the level of capital losses in Ukraine was higher, as was the level of NPL (although taking into account the latest PrivatBank surveys and changing the methodology for determining non-performing loans). This means that the starting positions of the transition to new capital requirements are worse for the domestic economy, and therefore the trajectory of capital build-up should be higher. This will increase financial stability and strengthen owners' responsibility of financial institutions. Changes in the approaches to banking regulation, theoretically addressed to the problem of procyclicality and strengthening financial stability show a significant potential for overcoming the negative manifestations of banking activity among weak institutions. This is largely due to the fact that weak institutions accelerate typical manifestations of the banking system vulnerability to procyclicality and risk concentration. A typical example is insider lending. In the expansion phase, lending to related parties reflects an attempt to expand control over assets in an expanding 
economy, with the result that risks are concentrated rather than diversified. The compression phase of maintaining this funding model reflects a sharp aggravation of the information asymmetry problem and protection of creditors' rights in the stressed economy. On the other hand, from the institutional environment in most cases will depend on how the owners of the banks will be prone to shifting risk to outsiders, and how 'blind' banking supervision will be. A comparison of how changes in approaches to banking regulation, can be addressed to a representative of vulnerabilities and instances of weak institutions, shows table. 1.

Table 1. Elements of the new approaches to banking regulation in the context of representative vulnerabilities and vulnerabilities in the environment of weak institutions

\begin{tabular}{|c|c|c|}
\hline Elements & A representative case & The case environment of weak institutions \\
\hline Basel III & $\begin{array}{l}\text { Strengthening the role of funding } \\
\text { from the owners and a decrease in } \\
\text { the value of high profit in the phase } \\
\text { of expansion. }\end{array}$ & $\begin{array}{l}\text { The incentives for owners to relocate risks to outsiders are } \\
\text { limited by the explicit increase in their responsibility. Reducing } \\
\text { the share of profit in the minimum capital requirements limits } \\
\text { the vulnerability of capitalization to manipulation of risk } \\
\text { assessments. }\end{array}$ \\
\hline $\begin{array}{l}\text { Changing the structure } \\
\text { of the minimum capital }\end{array}$ & $\begin{array}{l}\text { Limitations procycles in credit } \\
\text { behavior using the preservation of } \\
\text { part of liquid funds. }\end{array}$ & $\begin{array}{l}\text { Procyclicity is often a manifestation of predatory behavior and } \\
\text { unhealthy competition for market share. The introduction of } \\
\text { such requirements would limit excessive risk taking, beyond the } \\
\text { usual risk appetite. }\end{array}$ \\
\hline $\begin{array}{l}\text { The introduction of the } \\
\text { conservation buffer }\end{array}$ & $\begin{array}{l}\text { Additional capital requirements are } \\
\text { designed to implement the principle } \\
\text { of proportionality between the scale } \\
\text { of the bank and the potential } \\
\text { magnitude of the stress. This is } \\
\text { indirectly a way to deal with the } \\
\text { problems of too big to fail and too } \\
\text { big to resolve. }\end{array}$ & $\begin{array}{l}\text { The problem of moral hazard, which results in the phenomenon } \\
\text { too big to fail, often has a political manifestation, which may } \\
\text { lead to the dominance of negotiations of a large problem bank } \\
\text { with the advancement of the political and business interests of } \\
\text { the oligarchic group. The fiscal vulnerability of economies with } \\
\text { weak institutions limits the scope for a feasible maneuver to } \\
\text { resolve the solvency situation of large banks, resulting in a } \\
\text { tendency to conclude an oligarchic group instead of a } \\
\text { potentially better option for nationalization or forced } \\
\text { restructuring. The presence of such buffers would limit } \\
\text { manipulation of vulnerability for political and economic } \\
\text { domination. }\end{array}$ \\
\hline $\begin{array}{l}\text { The introduction of the } \\
\text { buffer for systemically } \\
\text { important banks }\end{array}$ & $\begin{array}{l}\text { Achieved by increasing the } \\
\text { responsibility of the owners and } \\
\text { imposes restrictions on the structure } \\
\text { of financing in order to reduce } \\
\text { vulnerability to market borrowings, } \\
\text { which often generate a significant } \\
\text { vulnerability. It weakens the } \\
\text { dependence of the capitalization on } \\
\text { the nature of the risk assessment. }\end{array}$ & $\begin{array}{l}\text { In addition to limiting the incentive for owners to shift the risk } \\
\text { to outsiders, the introduction of restrictions on the funding } \\
\text { structure frees capitalization requirements from the risk of } \\
\text { manipulations with the nature of risk assessment. Such an } \\
\text { assessment is the most effective way to reduce the risk of asset } \\
\text { rarities, especially taking into account the significant role of } \\
\text { insider lending. In essence, such an approach would better } \\
\text { discipline banks compared to traditional capital requirements, } \\
\text { which include risk weighted assets. }\end{array}$ \\
\hline
\end{tabular}

Note: Compiled by the author.

At the same time, changes in capital requirements are only part of a large-scale change in banking regulation. The transformation of banking supervision in the direction of a risk oriented approach will strengthen the policy of banks capitalization. At the same time, overcoming political resistance to banking reforms will largely depend on how financial institutions will be able to go beyond the usual practices of related lending. Creating an adequate business climate and overall strengthening of the quality of institutions will create synergy with changes in banking regulation. Without this, reforms can affect the complication of the adaptation process to the new regulatory environment, in which banks will agree to increase the burden of transaction costs, while maintaining the usual practice of lending and risk assessment (in conjunction with an increase in the proportion of unloaded assets), instead of moving towards more diversified portfolios, which should be formed on the basis of market niches expansion.

\section{Conclusion}

The transition to the regulatory framework of Basel III as a response to the global financial crisis may well be imposed to address the weakness of the banking system due to the weakness of the institutions. The oligarchic banking, characterized by insider lending, concealing the ownership structure of creditors and borrowers, manipulating credit risk assessments, transferring risks to outsiders, etc., generated a fundamental vulnerability of Ukrainian banking system. Undercapitalization and understatement of credit risks have become the causes of a deep banking crisis. The ratio of risk weighted assets and assets in Ukraine increased only on the basis of recognizing the level of post-exposure credit risks, while the formal adequacy of capital adequacy to current 
standards did not guarantee resistance to the problem of bad debts. The environment of weak institutions radically manifests the problem of pro-cyclicality and concentration of risks, adding political risks to the continuation of structural reforms. The transition to Basel III in Ukraine, together with the construction of risk oriented oversight, is intended to lay the long-term structural preconditions for strengthening the resistance of the banking system. Creating a favorable business climate lending will allow a more flexible adaptation to the new regulatory environment.

\section{References}

1. BIS (2010). Basel III: A Global Regulatory Framework for More Resilient Banks and Banking System. Basel. BIS. June.

2. BIS (2013). Global Systemically Important Banks: Updated Assessment Methodology and the Higher Loss Absorbency Requirements. Basel. BIS. July.

3. Baker M., Wurgler J. (2013). Do Strict Capital Requirements Raise the Cost of Capital? Bank Regulation and the Low Risk Anomaly. NYU Working Paper. FIN-13-003.

4. Kashyap A., Rajan R., Stein J. (2008). Rethinking Capital Regulation. In Proceedings-Economic Policy Symposium Jackson Hole. Federal Reserve Bank of Kansas City.

5. Santos J. (2000). Bank Capital Regulation in Contemporary Banking Theory: A Review of the Literature. BIS Working Paper. 90, 1-40.

6. Dagher J., Dell'Ariccia G., Laeven L., Ratnovski L., Tong H. (2016). Benefits and Costs of Bank Capital. IMF Staff Discussion Note. SDN/16/04, 1-38.

7. Dimand D., Rajan R. (2000). A Theory of Bank Capital. NBER Working Paper, 7431, 1-58.

8. BIS (2010). An Assessment of the Long-term Economic Impact of Stronger Capital and Liquidity Requirements. Basel. August.

9. Gambacorta L., Song Shin H. (2016). Why Bank Capital Matter for Monetary Policy. BIS Working Paper. $558,1-34$.

10. Gambacorta L., Karmakar S. (2016). Leverage and Risk Weighted Capital Requirements, BIS Working Paper.586, 1-38.

11. Tirole J. (2006). The Theory of Corporate Finance. Princeton: Princeton University Press.

12. La Porta R., Lopez-de-Silanes F., Zamarripa G. (2003). Related Lending. Quarterly Journal of Economics. $118(1), 231-267$.

13. Rajan R. (1992). Insiders and Outsiders: The Choice Between Informed and Arms-Length Debt. Journal of Finance, 7. pp. 1367-1400.

14. La Porta R., Lopez-de-Silanes F., Shleifer A., Vishny R. (1997). Legal Determinants of External Finance. Journal of Finance, 52(3), 1131-1150.

15. Cull R., Haber S., Imai M. (2006). All Bad, All of the Times? Related Lending and Financial Development. Stanford Center for International Development, 1-56.

16. Laeven L., Valencia F. (2012). Systemic Banking Crises Database: An Update. IMF Working Paper. $\mathrm{WP} / 12 / 163,1-32$. 